\title{
Metallic Glass Bio-Material Development
}

\section{王 新敏 秦 風香 和田 武 孫根洙 木村 久道（東北大金研） \\ 楊 蜸金（天津大学） 井上 明久（東北大 WPI）}

X.M.Wang F.X.Qin T.Wada K.S.Son H.Kimura. Institute for Materials Research,

Tohoku University 2-1-1 Katahira, Aoba-ku, Sendai Japan

A. Inoue. Tohoku University, WPI 2-1-1 Katahira, Aoba-ku, Sendai Japan

X.J.Yang. Tianjin University, 92Weijin rod nankaiqu Tianjin China

まえがき

バイオマテリアル(Bio-Material) とは“ヒトの細胞 に接触して用いられる治療用材料”と定義され、日本 で『生体材料』と言っている。現在, 使用されている 生体材料は金属、セラミックス、合成高分子、天然高 分子に分類されている。これらの生体材料を用いて, 治療のための手術器具や血液バッグなどのほか, イン プランドの人工骨や人工血管および人工臟器など, 様々な分野で応用している。

金属系バイオマテリアルはステンレス鋼, コバルト ークロム合金, チタン合金, チタンーニッケル系形状 記憶合金および歯科用貴金属などがある。これらの材 料の最大の特徴は優れた機械的性質である。ところが, 金属系バイオマテリアルの中に添加元素により生体 に毒性反応がよく行われている。体内に埋め込まれる 金属材料の溶出物や材料の摩耗によって生じた金属 イオンは,体内の核酸やタンパク質などの生体分子と 反応すると, 細胞障害や発ガンなどが発生する。 例えば、優れた力学特性を持つ生体材料としてよく使 用されているステンレス鋼，コバルトークロム合金， 記憶合金及び 6-4 チタン (Ti-6Al-4V) 合金などの金 属系バイオマテリアルの中で、問題となっている強い 毒性反応を行う元素はニッケルやバナジウムやクロ 厶などである。これらの毒元素が多く含まれているた め、患者さんに上述のような病気で新しい苦痛を与え ている。更に、金属材料の毒性の問題だけではなく、 人工関節の耐摩耗性が不足で発生された摩耗粉が人 体組織への炎症反応の問題、人工骨格へ HAP の成長が 不適合の問題などは、材料開発者が解決しなければな らないことである。それで、ニッケル，バナジウム、 クロムなどの毒性元素を含まない人体に毒性が認め られない合金、人工器官の表面に生体適合性を改善す る表面活性化膜の成長技術の開発が非常に期待され ている。

近年、数多くの研究結果により生体適応性に優しい 元素をチタン基に添加して, 作製したニッケル, バナ ジウム、クロムフリーの生体に専用のチタン結晶合金、 特に力学特性が抜群の金属ガラス合金及び青の表面 の活性化処理技術の開発が注目されている。

本研究の目的は毒性元素 $\mathrm{Ni}$ が含まれていない合金 で高強度、低ヤング率、高疲労特性、高耐食性、生体 適応性が良好な新規な金属ガラスを開発することで ある。さらに、強固で、安定なアパタイトを成長する ことができる金属ガラス表面の作製技術を確立し、複 雑な形状の金属ガラス製品の作製技術を開発するこ
とである。具体な研究内容として、（1）アパタイト 粒子等骨成長を誘導する元素を含んだ新規な $\mathrm{T}$ i 基金 属ガラスの創製、（2）金属ガラスの表面活性化膜生 成の研究、（3）骨の類似性を有するポーラス状バル ク金属がラスの作製技術開発 (4) 難加工の金属ガラ スにより人体器官への作製技術の確立を行う。最終目 標としてFig.1 に示したように体内用の人工歯根、歯 冠、人工関節、プレート及び生体細胞に接触する体外 用の医療機器などに応用する。

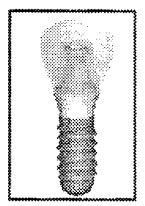

tooth

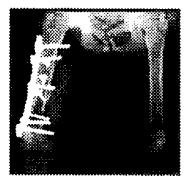

Plate

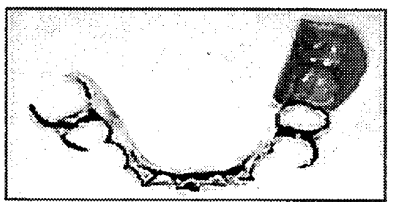

Crownwork

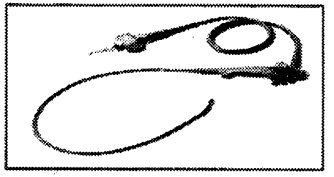

adapter of endoscope

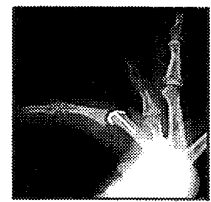

joint

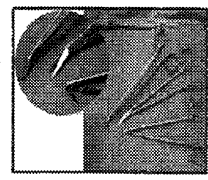

Scissors
Fig. 1 Application example

研究結果

(1) 新規な $\mathrm{Ti}_{40} \mathrm{Cu}_{36} \mathrm{Zr}_{10} \mathrm{Pd}_{14}$ 金属ガラス (1)組成を見出 した。Fig. 2 に示したこの組成の最大直径は $7 \mathrm{~mm}$ あ。

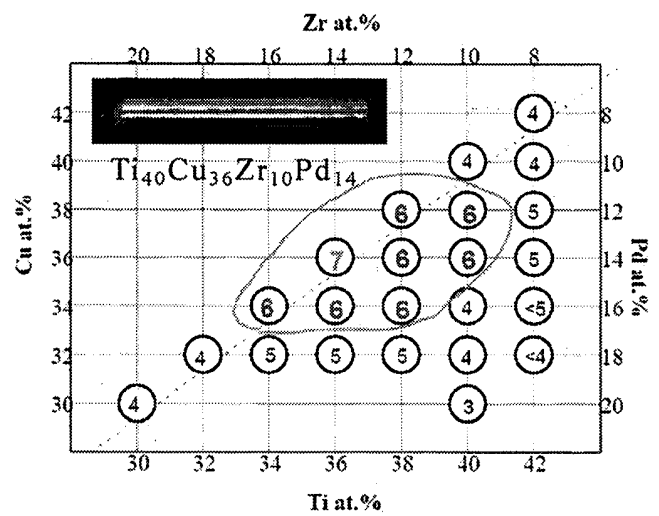

Fig. 2 Critical diameters (mm) of rod samples with full glassy structure for $(\mathrm{TiZr})_{50}(\mathrm{CuPd})_{50}$ alloys

この合金の機械的性質の圧縮強度、硬度、ヤング率 はそれぞれ $2000 \mathrm{MPa} 、 580 \mathrm{Hv} 、 90 \mathrm{GPa}$ である。このよう な高強度、高硬度およびしなやか性を持つ金属ガラス 合金は汎用の Ti 合金材料より耐摩耗性をはじめ、人 工骨格、人工関節、人工歯根などの応用によい力学性

日本機械学会〔No. 08-53〕第 21 回バイオエンジニアリング講演論文集（’09-1. 23〜24 札幌） 
を期待することができる。更に $\mathrm{Ti}_{40} \mathrm{Cu}_{36} \mathrm{Zr}_{10} \mathrm{Pd}_{14}$ 金属 ガラス合金に骨成長の誘導元素 $1 \%(\mathrm{at})$ の $\mathrm{Ca}$ や HAP を添加して、4 金属ガラスのバルクを作製した。それ を基盤としてその後のアパタイトが成長できると考 えられる。

新規な $\mathrm{Ti}_{40} \mathrm{Cu}_{36} \mathrm{Zr}_{10} \mathrm{Pd}_{14}$ 金属ガラス合金の耐食性は 従来の人工骨材料の Ti90Al6V4 (wt\%) 合金よりよい ことが確認された ${ }^{(2)}$ 。Fig. 3 に示したのはハンクス溶 液の中アノード分極曲線である。急冷鋳造バルクおよ び $693 \mathrm{~K}$ と $723 \mathrm{~K} \times 10 \mathrm{~min}$ の熱処理を行うことにより、 耐食性が上昇したことがわかった。この温度でナノ結 晶粒子が生成したので、強度が上がるだけではなく、 693K の場合塑性伸びも起こることが見られた。

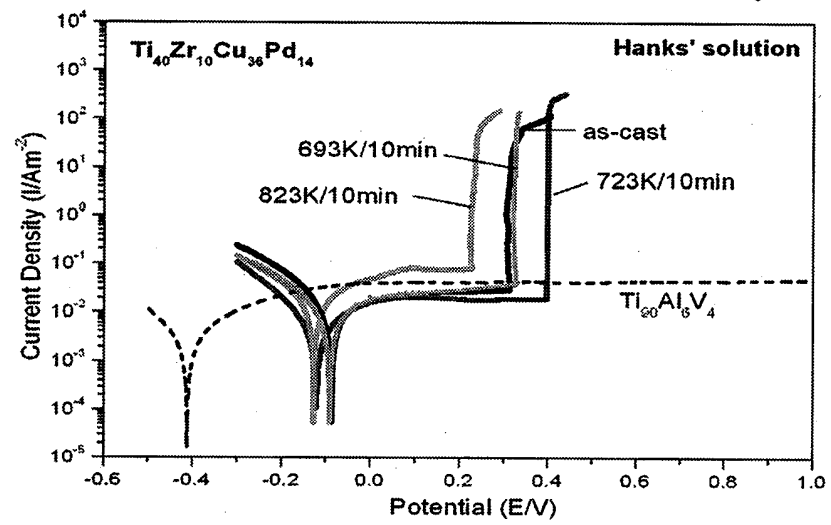

Fig. 3 Potentiodynamic polarization curve of $\mathrm{Ti}_{40} \mathrm{Cu}_{36} \mathrm{Zr}_{10} \mathrm{Pd}_{14}$ in Hanks solution

（2）金属ガラスの表面活性化膜生成ができた。以上 の無毒性、高強度、高弾性、優れた耐食性を有する新 規な金属ガラスを用いて、われわれは水熱法を用いて 根状の CaTi03/A1203/Ti3A1+Ti2A1 活性化膜 (GIL) を 生成して、更に、その表面に緻密な HAP 膜の快速生成 技術を確立した。Fig. 4 に示したのは $\mathrm{Ti}_{40} \mathrm{Cu}_{36} \mathrm{Zr}_{10} \mathrm{Pd}_{14}$ 金属ガラス合金を水熱処理処置で表面に GIL 膜を生 成して、更に緻密な HAP 膜を生成した積層の SEM 像で ある。この生体活性膜と金属ガラスの界面を大きく拡 散した連続層、あるいは積層とするものは金属ガラス 合金中の成分を種にして根の生えた成長層とし、更に それを低温で成長させることができるので、応力集中 が避けられ、結果として割れを防ぐことが可能になる。

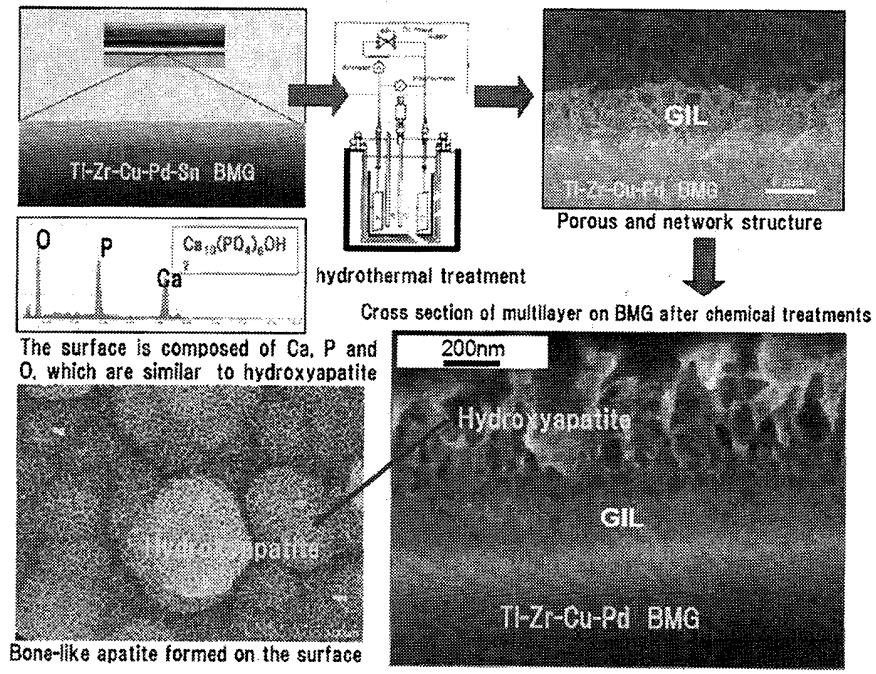

Fig. 4 Surface processing of $\mathrm{Ti}_{40} \mathrm{Cu}_{36} \mathrm{Zr}_{10} \mathrm{Pd}_{14}$

( 3 )骨の類似性を有するポーラス状バルク金属がラ
スの作製技術を開発した。ポーラス金属ガラスは金属 ガラスそのものの特徵である高強度及び高耐食性を 有しているうえ、ポアによる表面積増大や生体組織親 友サイト形成が期待されるため、生体材料として利用 できると考えられる。作製のために加圧含浸法ースペ 一サとする酸化物粉末を焼結して、その空隙に溶解し た金属ガラス生成のできる合金を高圧で圧入した後、 急冷させ、得られた金属ガラスと酸化物粉末複合材料 を一定濃度の酸化溶液に浸漬し、酸化物粉末のみ除去 することでポーラス金属ガラスを得る技術を開発し た。更に高圧雰囲気法及び粉末冶金焼結法なども開発 した。Fig. 5 は加圧含浸法により作製したポーラス金 属ガラスの断面とポア壁である。ポアが存在するポー ラス金属ガラスの機械的性質をコントロールするこ とができる。Fig. 6 に示されたように $20 \mathrm{GPa}$ のヤング 率を確認し、人間の大腿骨のヤング率に最も近いもの が得られた。

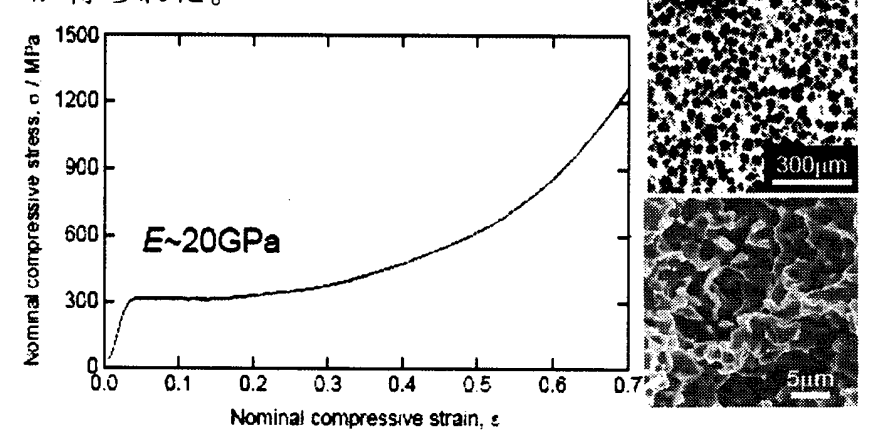

Fig. 5 Strain-Stress curve of Pd-Porous BMG and its cross section (a) and pore wall (b)

(4) 難加工の金属ガラスにより人体器官への作製技 術の確立は応用に極めて重要である。金属ガラスは結 晶合金の焼入れ相当の高強度、高硬度を有し、伸び率 が低いため、冷間塑性変形や切削加工は困難である。

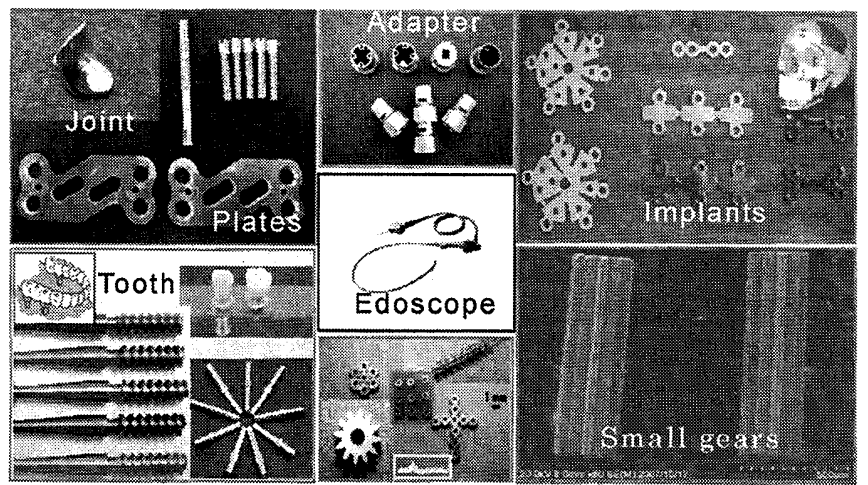

Fig. 6 BMGs for biomedical implants and parts for medical devices

そのため、われわれは金属ガラスの作製技術一中空 鋳造法、溶湯接合法、フォトエチング法、射出成形法、 表面処理法、及び切削により表面変質層の制御、切削 専用工具の開発などの方法を確立したことにより Fig. 6 に示した人工器官の人工指関節、プレート、人 工歯根、頭骨固定器具と医療器具の内視鏡先端探査部 のアダプタ、血管治療用モータ減速用の歯車系列を作 製することができた。

参考文献

1) L. Zhu, X. M. Wang, F.X. Qin, A. Inoue, Mater. Sci. Eng. A, 459 (2007) 233-237

2) F. X. Qin, X. M. Wang, A. Kwashima, S. 1. Zhu H. Kimura A. Inoue, Mater. Trans. Vol. 47 No. 8 2006) 1934-1937 